(2) Open Access Full Text Article

\title{
Importance of digital palpation as a routine technique for intraocular pressure estimation in primary care settings
}

This article was published in the following Dove Press journal:

Clinical Optometry

24 September 2010

Number of times this article has been viewed

\section{Fatemeh Heidary \\ Reza Gharebaghi \\ Roghayeh Heidary \\ Amir Hasan Gharebaghi}

Middle East Cancer Institute,

Tehran, Iran
Correspondence: Reza Gharebaghi Middle East Cancer Institute,

PO Box I 4I 55-I856, Tehran, Iran

Tel +98 2 I4 449 I 457

Fax +98 2I4 $449 \quad 1457$

Emailinfo@meptic.com
Abstract: Acute angle-closure glaucoma is constituted an ocular emergency. The result is a pronounced elevation of intraocular pressure (IOP), with redness of the eye, and moderate to severe pain. Palpation is one of the oldest and simplest methods for approximate IOP assessment. Gentle palpation through closed lids often confirms that the involved eye is much harder than the uninvolved eye. In this commentary, we recommend that this technique be used routinely in primary and emergency care settings for patients who have suspected glaucoma. Examiners may assess the accuracy of their findings by using tonometers. With minimal training, examiners may improve their expertise with the technique and the accuracy of their assessment. This technique may aid the diagnosis of glaucoma in the primary care and emergency settings especially when other methods are unavailable or subject to gross error or calibration.

Keywords: digital palpation, intraocular pressure, primary care settings

Glaucoma is one of the main causes of permanent blindness worldwide, ${ }^{1}$ and progression from acute glaucoma to blindness is imminent in the absence of prompt treatment.

Acute glaucoma involves narrowing of the anterior chamber such that the aqueous outflow is obstructed, leading to a massive increase in the intraocular pressure (IOP). Associated symptoms include a severe throbbing or piercing pain in the eye, accompanied by nausea and vomiting. Visual acuity is significantly impaired, and the patient sees halos around lights. On examination, the eye appears red; the cornea is hazy; and the pupil is oval, fixed, and semidilated. On palpation, the eye feels firm owing to elevated IOP. ${ }^{2}$

Elevated IOP is the main and an important treatable risk factor for glaucoma. ${ }^{3}$ Nevertheless, studies showed raised IOP may be significantly more common in patients with chronic intraocular inflammation or rarely with intraocular tumors. ${ }^{4,5}$ Various methods for assessing IOP are available, such as palpation, manometry, and tonometry. However, most of these techniques require expertise of an ophthalmologist and may employ expensive tools. In the absence of such facilities, IOP can be assessed by digital palpation. This is especially useful in emergency rooms, in the case of patients presenting with pain and redness in the eye.

The technique for digital palpation is as follows: The patient closes his/her eyes and looks downward. Using the index finger of both hands, the examiner gently applies pressure to the superior part of closed lids alternately, to estimate the force required to indent the orbital wall. With digital palpation, IOP can be estimated with high accuracy, perhaps with a difference of only 2-3 mm Hg from that determined using an accurate measuring 
device. ${ }^{6}$ In fact, Baum et al found digital palpation to yield a moderate success rate for identifying elevated IOP and concluded that although this technique is perceived to be inaccurate, it can definitely alert physicians to marked increases in IOP (>30 mm Hg). ${ }^{7}$ Another study revealed that digital palpation is reliable for estimating the IOP of young children. ${ }^{8}$

In this backdrop, we recommend that primary health workers and optometrists routinely perform digital palpation on patients who present with redness in the eye, and assess the accuracy of their findings by using tonometers. With minimal training using an eye model, individuals can improve their expertise with the technique and the accuracy of their estimation.

Thus, digital palpation is a simple technique that can prove very useful for assessing IOP in primary healthcare settings, particularly in the absence of equipment, for example, in healthcare centers located in rural areas or in developing countries. Accordingly, this technique can also aid the diagnosis of high IOP in primary and emergency care settings.

\section{Disclosure}

The authors report no conflicts of interest in this work.

\section{References}

1. Friedman DS, Wolfs RC, O'Colmain BJ, et al. Prevalence of open-angle glaucoma among adults in the United States. Arch Ophthalmol. 2004;122: 532-538.

2. Wirbelauer C. Management of the red eye for the primary care physician. Am J Med. 2006;119:302-306.

3. Sit AJ, Liu JH. Pathophysiology of glaucoma and continuous measurements of intraocular pressure. Mol Cell Biomech. 2009;6: $57-69$.

4. Escalona-Benz E, Benz MS, Briggs JW, Budenz DL, Parrish RK, Murray TG. Uveal melanoma presenting as acute angle-closure glaucoma: report of two cases. Am J Ophthalmol. 2003;136:756-758.

5. Herbert HM, Viswanathan A, Jackson H, Lightman SL. Risk factors for elevated intraocular pressure in uveitis. J Glaucoma. 2004;13:96-99.

6. Choplin NT, Lundy DC. Atlas of Glaucoma. London, UK; Martin Duniz; 1998.

7. Baum J, Chaturvedi N, Netland PA, Dreyer EB. Assessment of intraocular pressure by palpation. Am J Ophthalmol. 1995;119:650-651.

8. Ficarra AP, Sorkin R, Morrison C. Assessment of intraocular pressure in children by digital tension. Optometry. 2002;73:499-506.
Clinical Optometry

\section{Publish your work in this journal}

Clinical Optometry is an international, peer-reviewed, open access journal publishing original research, basic science, clinical and epidemiological studies, reviews and evaluations on clinical optometry. All aspects of patient care are addressed within the journal as well as the practice of optometry including economic and business analyses. Basic and clinical

\section{Dovepress}

research papers are published that cover all aspects of optics, refraction and its application to the theory and practice of optometry. The manuscript management system is completely online and includes a very quick and fair peer-review system, which is all easy to use. Visit http://www.dovepress. com/testimonials.php to read real quotes from published authors. 